Proceeding Paper

\title{
Harnessing Ocean Energy from Coastal and Offshore Pakistan ${ }^{\dagger}$
}

\author{
Shahid Amjad
}

check for updates

Citation: Amjad, S. Harnessing Ocean Energy from Coastal and Offshore Pakistan. Eng. Proc. 2021, 12, 78. https://doi.org/10.3390/ engproc2021012078

Academic Editor: Muhammad Bilal Niazi

Published: 10 January 2022

Publisher's Note: MDPI stays neutral with regard to jurisdictional claims in published maps and institutional affiliations.

Copyright: (C) 2022 by the author. Licensee MDPI, Basel, Switzerland. This article is an open access article distributed under the terms and conditions of the Creative Commons Attribution (CC BY) license (https:// creativecommons.org/licenses/by/ $4.0 /)$

\author{
Department of Environment \& Energy Management, Institute of Business Management (IoBM) \\ Karachi 75190, Pakistan; Shahid.amjad@iobm.edu.pk \\ † Presented at the 1st International Conference on Energy, Power and Environment, Gujrat, Pakistan, \\ 11-12 November 2021.
}

\begin{abstract}
There is potential for harnessing renewable energy from coastal waves and tides, from the coastal and offshore areas of Pakistan. The Sindh coast is a complex creek network located in the $170 \mathrm{~km}$ of the Indus deltaic area. The flood and ebb of tides in and out of these creeks have a high velocity of $0.2-0.5 \mathrm{~m} / \mathrm{s}$. NIO Pakistan has conducted preliminary feasibility surveys for energy extraction from the Indus deltaic creek system. The 17 major creeks have the capacity to produce estimated energy of approximately $1100 \mathrm{MW}$. The seawater ingresses inland at some places up to $80 \mathrm{~km}$ due to the tidal fluctuation, which is favorable for energy extraction from tidal currents in coastal Sindh. In total, $71 \%$ of our Planet Earth is covered by the oceans. The oceans are massive collectors of solar radiation received from the sun. The oceans store the potential energy that is received in the form of incident radiation from the sun that generates thermal energy. A $10{ }^{\circ} \mathrm{C}$ temperature difference can be harnessed between the surface and bottom water, using a working fluid. The thermal difference absorbed by the oceans can be converted into electricity through ocean thermal energy conversion (OTEC). The ocean tidal and wave energy has advantages over energy produced using different fossil fuels; there are also several benefits of using renewable sources of ocean energy. Viability of ocean energy in Pakistan is discussed in this paper.
\end{abstract}

Keywords: ocean energy; tides; waves; offshore; Pakistan

\section{Introduction}

The largest collectors of solar energy are the oceans. The sun is the ultimate power house of our Planet Earth. Surface water evaporation from oceans provides rain and fresh water for crops, drinking water and power for hydro generation. Forests and our food crops grow through the photosynthesis process. It powers the weather to provide winds. The sun stores some of its energy. The greenhouse gases keep the earth warmed up to an average temperature of about $15^{\circ} \mathrm{C}$ [1]. The warm water in the Indian Ocean could be harnessed to benefit more than 1 billion people. If there were no ocean currents and circulation generated that is caused by the surplus heat at the equator, Europe would freeze over. The gravitational forces exercised by the sun and the moon cause tides. The waves' energy is driven by winds. The coastal areas of Karachi experience two high and two low tides over a period of $24 \mathrm{~h}$. The tides and waves are renewable sources of energy. This potential energy can be harnessed into electricity by the conversion of both wave energy and tidal energy that usually involves mechanical devices. The tidal amplitude range in Karachi coastal areas between low and high tides is $-0.1-4.5 \mathrm{~m}$. The Indus deltaic area has a network of creeks along the $170 \mathrm{~km}$ coastal belt. Can we harness the potential energy from the coastal creeks?

\section{Methodology \\ 2.1. Thermal Energy Ocean, Thermal Energy Conversion (Closed Cycle)}

The ocean surfaces are the largest collectors of incoming solar radiation. The incident radiation received from the sun warms the surface seawater; temperatures in the Arabian 
Sea on the average range from 24 to $28^{\circ} \mathrm{C}$. The bottom oceanic waters below $500 \mathrm{~m}$ range from 10 to $15{ }^{\circ} \mathrm{C}$. The OTEC technique [2] harnesses the difference in the temperature between the warm upper ocean surface layers and the cooler water temperatures below $500 \mathrm{~m}$. A vaporizing working fluid (ammonia/propane) is used in circular pipes. The vapor in the pipes expands and turns a turbine at moderate pressure. The turbine is attached to a generator having a capacity to produce electricity. The working fluid vapor is cooled in a heat exchanger (condenser) using cold seawater from the ocean depths. OTEC systems are either closed-cycle or open-cycle systems. Working fluids that are typically thought of as refrigerants such as ammonia, propane, etc. are used in OTEC closed cycle. The condensed working refrigerant fluids are then pumped back into the evaporator to repeat the cycle. The refrigerant fluid continuously circulates and remains in a closed-cycle system (Figure 1).

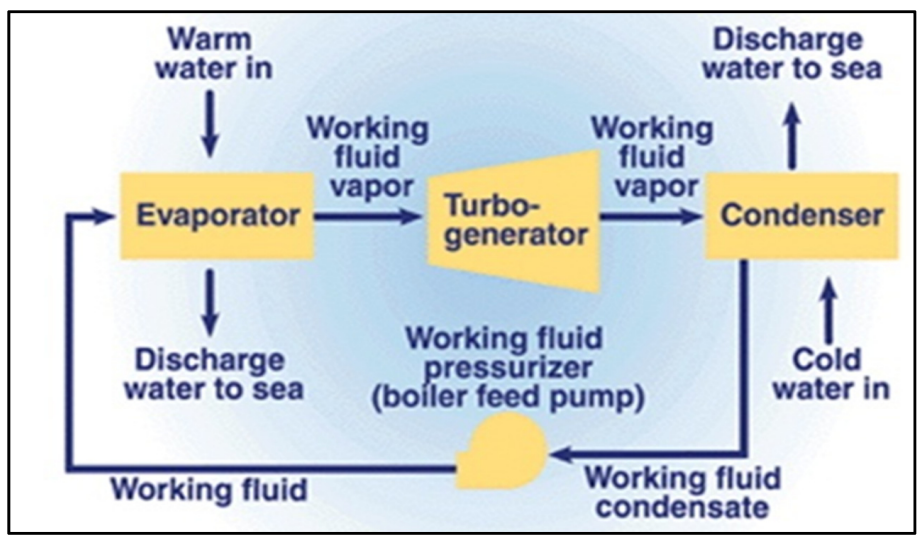

Figure 1. OTEC closed cycle. Source: Wikipedia 2015.

Application of Ocean Thermal Energy Conversion Locations Offshore Pakistan

Three locations have been identified in Pakistan's offshore areas for the extraction of energy using the OTEC method [2]. These potential offshore locations are off Astola Island, off Churna Island and the Indus Canyon (Figure 2).

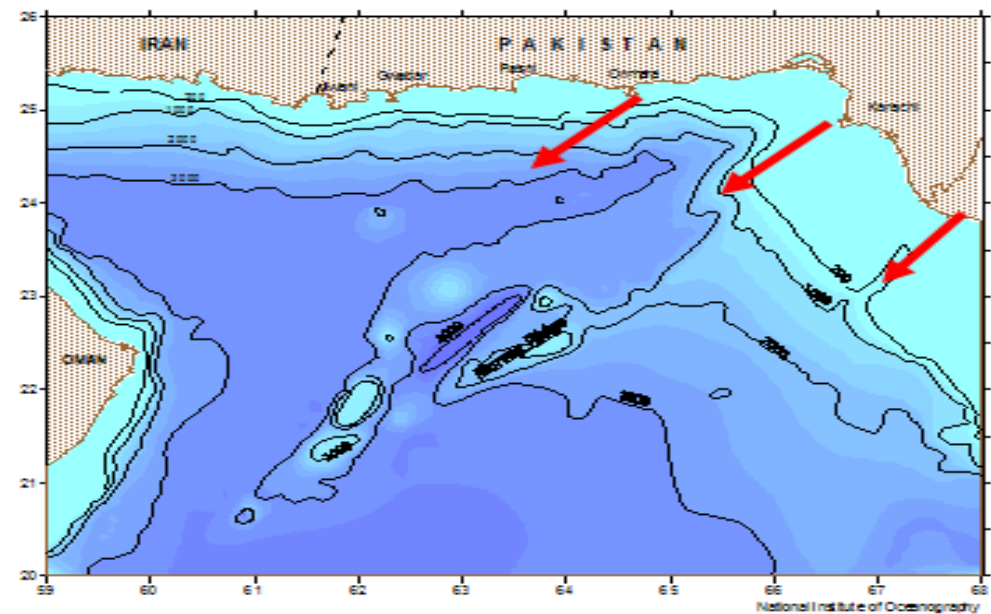

Figure 2. Potential offshore locations for ocean thermal energy in Pakistan (NIO).

\subsection{Mechanical Energy}

\subsubsection{Harnessing Tidal Power on the Sindh Coast}

The Indus deltaic area of $170 \mathrm{~km}$ off Karachi is a complex area. This region has a meandering network of creeks (Figure 3). Tidal water during high and low tides moves in and out of these creeks during ebb and flow tides at velocities of $0.2-0.5 \mathrm{~m} / \mathrm{s}$ [3]. In other 
parts of coastal Sindh, seawater moves inland up to $60 \mathrm{~km}$ due to lower land elevation and intense tidal fluctuation. These locations are also favorable for energy extraction from tidal currents. Pakistan's coast experiences two semidiurnal tidal cycles. High and low tides ranging between -0.1 and $4.5 \mathrm{~m}$ have the potential for harnessing the energy to produce electricity.

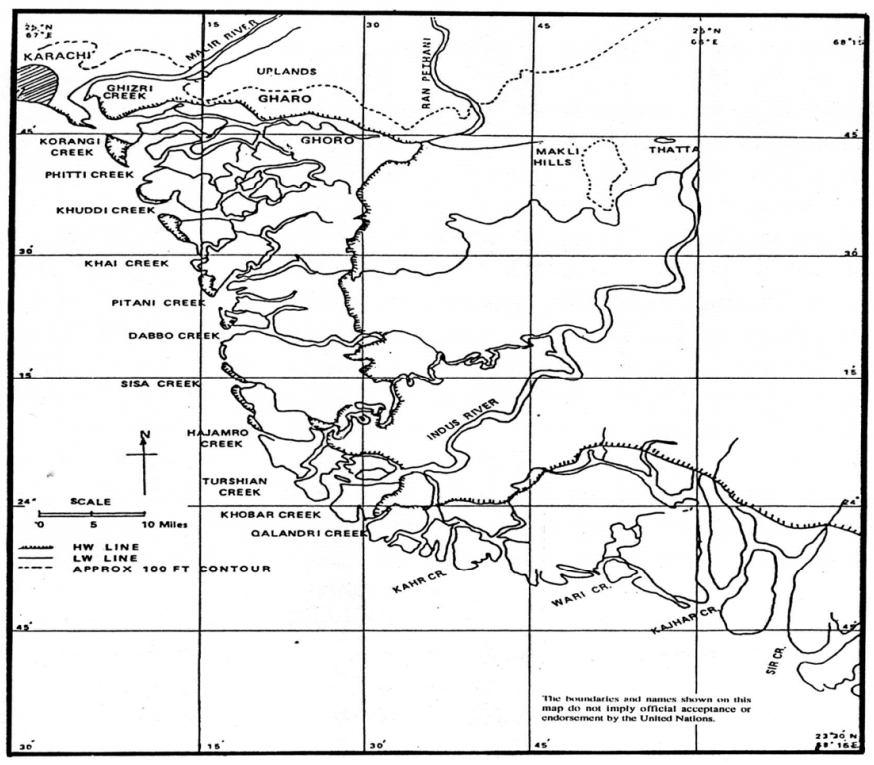

Figure 3. Creeks network system of the Indus delta.

Preliminarily, surveys and investigation carried out in some of the Indus deltaic creeks exhibited encouraging results. Energy can be harnessed from Korangi Creek near Karachi to Kajhar Creek in the vicinity of the Pakistan-India coastal border. The current intensity of 4-5 knots with velocities reaching up to 8 knots has also been recorded. It is estimated that approx. $1100 \mathrm{MW}$ of energy can be harnessed from these creeks [3].

\subsubsection{Harness the Wave/Tidal Power of Balochistan Coast}

Balochistan coast is an ideal location for harnessing the wave and tidal power. The potential locations along the Makran coast are Ormara and Gwadar sites, Figure 4.
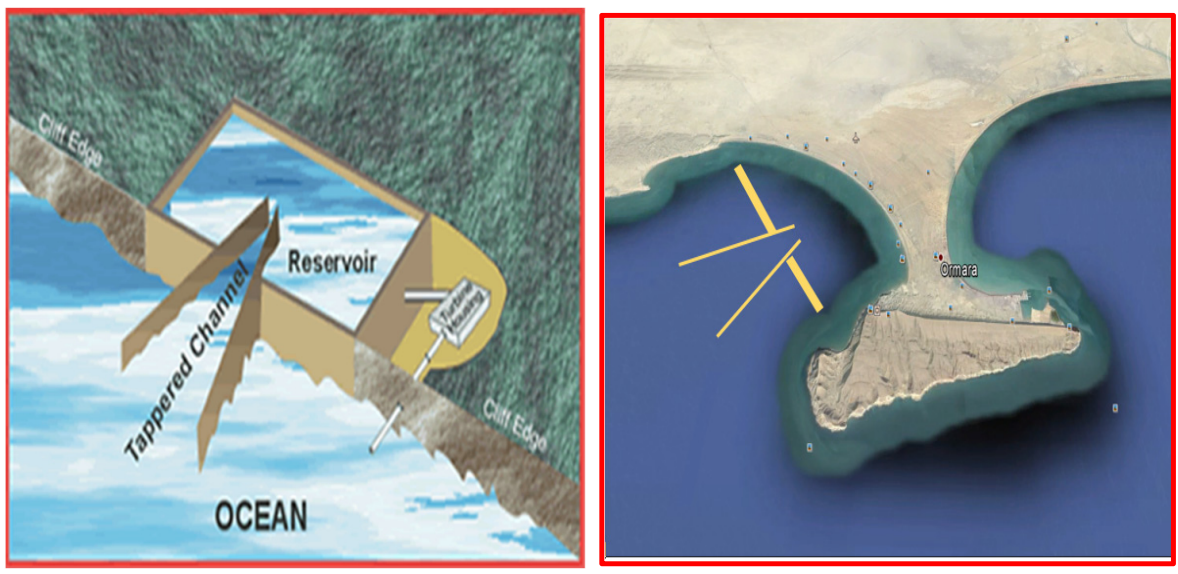

Figure 4. Potential locations along the Makran coast.

\section{Energy Calculations}

The tapered channel methodology contains a gradual narrow channel. The heights of the wall are approximately 3 to $5 \mathrm{~m}$ above the mean water level. Progressive waves enter 
the channel; as the waves propagate down the narrow channel, the wave peak is amplified till the wave crests spill over the walls and accumulate in a reservoir. The stored seawater in the reservoir provides a strong source of water supply to a conventional low-head turbine. The energy to be harnessed from this device is dependent on the volume of the water stored in the reservoir. The potential energy contained in a volume of water in the stored reservoir can be calculated by:

$$
\mathrm{E}=\frac{1}{2} A \rho g h^{2}
$$

The potential energy available in the water stored in the reservoir is dependent on the volume of water. The energy potential contained in a volume of water in the reservoir is:

- $\mathrm{E}=$ potential energy,

- $\quad h$ is tidal range (vertical),

- $A$ is the area of the reservoir basin,

- $\rho$ is the water density $=1025 \mathrm{~kg} \mathrm{~m}^{3}$ (seawater density fluctuates between 1021 and $1030 \mathrm{~kg} \mathrm{~m}^{3}$ ),

- $\quad g$ is Earth's gravity $9.81 \mathrm{~m}$ per second squared.

\section{Advantages of Ocean (Tidal and Wave) Energy}

- $\quad$ Tidal and wave energy is free, renewable and a clean energy source.

- The use of tidal and wave energy has many advantages over available fossil fuels. Mostly, the dependence on energy from fossil fuels is reduced.

- There is no liquid or solid pollution from tidal and wave energy consumption.

- Tidal power is $80 \%$ more efficient compared to coal and oil.

- Harnessing the power of high-energy waves, the shoreline will be protected from sediment erosion.

- About $1100 \mathrm{MW}$ of electricity generation can occur from tides along the coast of Pakistan.

- $\quad$ Tides are renewable and active 24/7, 365 days.

\section{Conclusions}

Pakistan has the ability to produce ocean thermal power from the exclusive economic offshore areas (EEZ). The Sindh coast has a network of 17 meandering creeks in the $170 \mathrm{~km}$ of the Indus delta. This region can produce electricity by using mechanical power from the tides and waves. The ebb and flow of water in and out of the creek system during high and low tides with high velocity $(0.2-0.5 \mathrm{~m} / \mathrm{s})$ throughout the year makes it feasible to extract ocean energy. Although this energy is free and renewable, it is capital-intensive and requires high maintenance costs. The preliminary feasibility surveys performed by NIO Pakistan estimated the extraction energy along the Indus delta creeks and the Makran coastal area at $1100 \mathrm{MW}$.

Institutional Review Board Statement: Not applicable.

Informed Consent Statement: The current study does not involve patient consent.

Data Availability Statement: NIO Archives http://niopk.gov.pk/NODC.html (accessed on 25 December 2021).

\section{References}

1. What Is the Greenhouse Effect. Available online: https://www.acs.org/content/acs/en/climatescience/climatesciencenarratives/ what-is-the-greenhouse-effect.html (accessed on 25 December 2021).

2. Ocean Thermal Energy Conversion-Wikipedia 2015. Available online: https://en.wikipedia.org/wiki/Ocean_thermal_energy_ conversion (accessed on 25 December 2021).

3. National Institute of Oceanography (NIO Pakistan) Archives 2000. Available online: niopk.gov.pk/NODC.html (accessed on 25 December 2021). 